
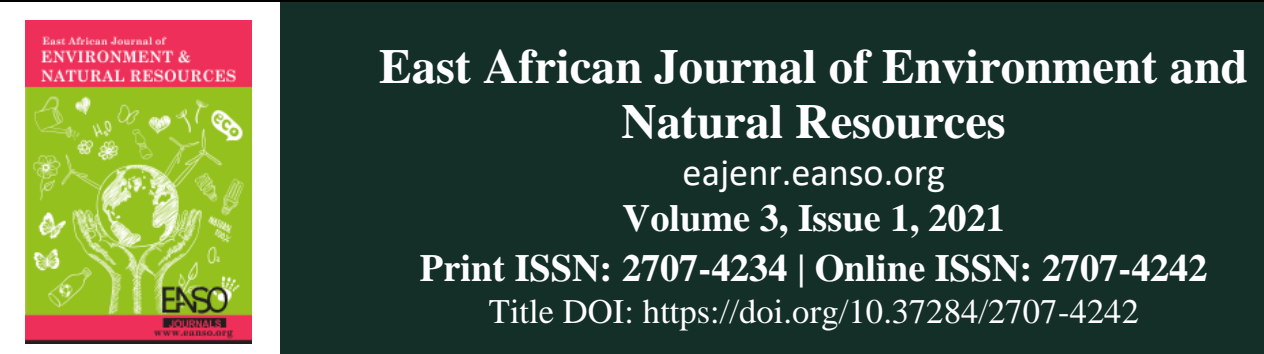

Original Article

\title{
Ethical Evaluation of Environmental Stewardship in Sub-Saharan Africa
}

\author{
Mark Omorovie Ikeke ${ }^{1 *}$ \\ ${ }^{1}$ Department of Religious Studies and Philosophy, Delta State University, PMB 1, Abraka, Nigeria. \\ ${ }^{*}$ Correspondence email: Ikeke7@yahoo.com
}

Article DOI: https://doi.org/10.37284/eajenr.3.1.302

\section{Date Published: ABSTRACT}

22 March 2021 It is an indisputable fact that the global climate change crisis is equally affecting Sub-Saharan Africa. Africa is inundated with a lot of environmental problems.

Keywords: These problems include pollution, land degradation, deforestation, desertification, extinction of endangered plants and animals' species,

Environmental, indiscriminate dumping of both domestic and industrial waste, drought, and so

Stewardship, forth. Environmental problems cause a great ordeal for humans. They lead to the

Sub-Saharan Africa,

Eco-Stewardship.

destruction of human habitation, the destruction of the habitat of plants and animals, the endangerment of water sources, the destruction of farmland and streams, etc. All these impacts the wellbeing of humans and other entities on the planet. Many environmental problems taking place in Africa are anthropogenic, which means that they are caused by human activities. This paper argues that in order for the Sub-Saharan population to overcome these environmental problems, they should believe and practice environmental stewardship or eco-stewardship. Through a hermeneutical and critical analytic method, the concept of ecostewardship is examined and critiqued. Some of the causes of environmental problems in Sub-Saharan Africa are also presented. The paper finds and concludes that environmental stewardship can help to curb or mitigate the environmental crisis in Sub-Saharan Africa.

\section{APA CITATION}

Ikeke, M. O. (2021). Ethical Evaluation of Environmental Stewardship in Sub-Saharan Africa. East African Journal of Environment and Natural Resources, 3(1), 69-77. https://doi.org/10.37284/eajenr .3.1.302

\section{CHICAGO CITATION}

Ikeke, Mark. Omorovie. 2021. "Ethical Evaluation of Environmental Stewardship in Sub-Saharan Africa". East African Journal of Environment and Natural Resources 3 (1), 69-77. https://doi.org/10.37284/eajenr.3.1.302.

69 This work is licensed under a Creative Commons Attribution 4.0 International License. 


\section{HARVARD CITATION}

Ikeke, M. O. (2021) "Ethical Evaluation of Environmental Stewardship in Sub-Saharan Africa", East African Journal of Environment and Natural Resources, 3(1), pp. 69-77. doi: 10.37284/eajenr.3.1.302.

\section{IEEE CITATION}

M. O. Ikeke, "Ethical Evaluation of Environmental Stewardship in Sub-Saharan Africa”, EAJENR, vol. 3, no. 1, pp. 69-77, Jun 2021.

\section{MLA CITATION}

Ikeke, Mark. Omorovie. "Ethical Evaluation of Environmental Stewardship in Sub-Saharan Africa". East African Journal of Environment and Natural Resources, Vol. 3, no. 1, Mar 2021, pp. 69-77, doi:10.37284/eajenr.3.1.302.

\section{INTRODUCTION}

Sub-Saharan Africa refers to all countries and the areas lying below the vast Sahara Desert in the African continent. While it is true that the area is a vast one and should not be the subject of overgeneralisation, it is equally true that there are commonalities common to the region that warrants examining the region as one. To speak of SubSaharan Africa does not mean there are no varieties in the countries in the region. Even within the common peculiar problems that the region faces like environmental problems, each country is impacted by these problems differently. However, in most of sub-Saharan Africa, the issues experienced are basically the same. Mabogunje is right to write that:

Sub-Saharan Africa suffers from some serious environmental problems, including deforestation, soil erosion, desertification, wetland degradation, and insect infestation. Efforts to deal with these problems, however, have been handicapped by a real failure to understand their nature and possible remedies. Conventional wisdom views the people of this region as highly irresponsible toward the environment and looks to the international community to save them from themselves. It tends to blame all of the region's environmental problems on rapid population growth and poverty. Yet, there is no conclusive evidence that Africans have not been particularly oblivious to the quality of the environment, nor has the international community shown any genuine concern for it until recently. Clearly, protecting the environment of Sub-Saharan Africa is an issue that needs to be examined more carefully and incorporated into an overall strategy of sustainable economic development (1998, p. 4).
More than ever before, governments in Africa and many nongovernmental organisations in the drive to achieve the Millennium Development Goals have embarked on various projects and campaigns to protect the environment. The problem is that much of the campaigns are not driven by deep-rooted nonanthropocentric ethics of preserving nature. It is driven by controlling natural resources for development. Wars in the region are fought to control more money or have a greater share in the national cake to build social infrastructure. This trend can be reversed by developing and promoting a deep ethic of environmental stewardship for the region. It should be said that the natural resources of the region are entrusted to the peoples by the divine creator for the wellbeing of present and future generations and of non-human life.

The idea of environmental stewardship, for short eco-stewardship, is one that could only be fully understood by drawing from resources in the religious and philosophic disciplines. The hermeneutics of environmental stewardship done here is from a religious-philosophic angle. After that interpretation has been made, some causes of the environmental predicament will be examined, followed by a critical appreciation of ecostewardship.

\section{Hermeneutics of Eco-stewardship}

The term environmental stewardship or ecostewardship will be used interchangeably. It is not possible to have a full understanding of the concept of stewardship without drawing some insights from religious traditions and secular perspectives. While it is true that the concept of stewardship is a common word in religious traditions, it is also used from the secular perspective. In The Chambers Dictionary, the word "stewardship" means "the office of a steward; management; the individual's

70 | This work is licensed under a Creative Commons Attribution 4.0 International License. 
functions of the practical work of the Christian church involving obligations to give a share of his time and goods to others" (1994). The same dictionary defines the word "steward" as, "a person who manages the domestic concerns of a family or institution; one who superintends another's affairs, especially an estate or farm; the person who oversees catering arrangements and general passenger's comfort on a ship, aircraft, etc." For The New Webster's Dictionary of the English Language, a steward is "a ship's officer in charge of stores and arrangements about meals; a male attendant who looks after the personal needs of passengers abroad ship; an employee on an airplane, train, etc. in charge of preparing and serving meals, etc." (1972).

There are two ideas rooted in the concept of stewardship or steward. They are the ideas of responsibility and accountability. The concept of a steward implies that someone has been entrusted with a function, duty, responsibility, and assignment that the person is to carry out on behalf of someone else. The steward is accountable and should report back for the duty he/she has been entrusted. The steward carries out the duties entrusted to him/her following the laws and regulations laid down for $\mathrm{him} / \mathrm{h}$ er. The steward is not the one who decides how to carry out the function. He/she follows specifications entrusted to him/her. The steward will be required to give an account or report. A steward must have the consciousness that he/she is not the one who determines the parameters of the work to be done. A steward must be firmly convinced that he/she is accountable to someone else or another entity. This must be the driving force behind the steward's work.

The word steward comes from the old English word, "stiweard." "Sti" means "all" and "weard" means "a guide." According to Bakken (2009) who collaborates the whole idea, "the two key elements of the stewardship concept are the ability to care for, manage, or control persons or things and accountability for the proper exercise of that ability. A steward exercises power and authority but does not have the licence to do so in a self-serving or careless manner" (p. 282). It is now important to describe what eco-stewardship is? Eco-stewardship means that humans are stewards of the entire planet or earth community. Every human being is an ecosteward or earth keeper. Both individually and collectively, humans are to take care of the land, water, atmosphere, organisms, plants and animal species.

It is important here to state the religious meaning and the secular perspective on stewardship. We draw from the Judeo-Christian perspective. The concept is rooted in the bible passage, Genesis 1: 26-31 and Genesis 2: 15. Humans are created in God's image and likeness. God entrusted the earth to them to cultivate and to be caretakers. Humans are not the makers or owners of the earth; they are to make use of the resources of the earth according to the mind of the creator. Their call to dominion is not to dominate. They are to serve as God's viceregents on earth. Psalm 24: 1 declares that the earth is the Lord's and the fullness thereof. The idea of stewardship is clearly demonstrated in the biblical parable of talent. Three stewards were entrusted with talents in that parable. They were to make use of them until the master returns. They were to do this faithfully and diligently. This is why in the parable of the wasteful steward in Luke 16; the wasteful steward was denounced for misusing his master's wealth.

In the Christian tradition the protestant reformer, John Calvin explicitly used the term with regard to Genesis 2:15 affirming that humans are stewards of God in all things and are to shun corruption and wastefulness (Bakken, 2005, p. 1598). Bakken also cites the English Chief Justice Matthew Hale who writes that with regard to this material world, humans are God's viceroy, steward, bailiff or farmer of this goodly farm to "preserve the face of the Earth in beauty, usefulness and fruitfulness" (Bakken, 2005, p. 1598). In short, in Christian parlance, it refers to the "responsibility to manage one's life and goods with proper regard to justice and the rights of others" (Gorman, 2007, p. 1322). God entrusts the earth to humans to care for and it is part of their obligatory service to the creator and faithful relationship with him (Jenkins, 2008, p. 77). These goods and resources, which include the earth comes from God and humanity has an obligation to share them (Gorman, 2007).

According to Bakken, "there are also significant uses of the term in a secular context suggesting that it need not assume a theistic or God-centred worldview. For example, there are secular 
organisations such as the Forest Stewardship Council, the Land Stewardship Project, and the Alberta Stewardship Network" who are concerned about stewardship (Bakken, 2009, p. 283). In the secular understanding of stewardship, humans are accountable to future generations and they have a responsibility to live sustainably in making use of earth's resources (Bakken, 2009). They are accountable to the international community for the fair distribution of resources and maintenance of the global environment. Public authorities have a responsibility for the stewardship of public lands and stewardship on behalf of citizens. It is important to note also that individuals could be held responsible for maintaining ecological values and those individuals are responsible for the community of life (Bakken, 2009). Attfield (2006) has shown that there are those who accept stewardship without God and he asks "to whom, then, or before whom would secular stewards be responsible?" (p. 87). In 1990 the Conservative government of Britain affirmed stewardship of ethical responsibility to future generations regarding environmental policies in their document, This Common Inheritance (Attfield, 2006, p. 87). There are indications of secular stewardship in human rights instruments. The idea of global partnership and ecoresponsibilities placed on states speaks of stewardship (United Nations Conference on Environment, 1992, Principle 7). States are to preserve the environment not simply for their own sake but for the good of other states. Stewardship obligates to another entity. The concept of sustainable development implies stewardship for development is to be done in such a way that it does not compromise the ability of future generations to meet their own needs (World Commission on Environment and Development 1987, chap 2).

\section{Causes of Environmental Predicament in Sub- Saharan Africa}

The word environment is defined in various ways. Yet, no matter how it is defined, it has to do with the surroundings of human beings and all other organisms. It "consists of all, or any, of the following media, namely the air, water and land; and the medium of air includes the air within buildings and the air within other natural or manmade structures above or below ground" (United Kingdom Parliament, 1990, part 1). By implication it implies "the entire global system. That is everything from the outermost reaches of the atmosphere to the earth's inner core. Inherent in this are all the factors that influence the environment from its geology to the fauna and flora as well as the prevailing climate" (Hook, 2008, p. 77). The word predicament means "difficult position, a plight or dilemma" (The Chambers Dictionary, 1994, p. 1348). Therefore, the term environmental predicament means the plight or problems involved in the human relationship with the planet, natural resources, or non-human animals and elements on the earth.

It is true that there is an environmental crisis plaguing humanity. Environmental predicament implies the problems that "arise from the deliberate or inadvertent abuse, misuse, and overuse of natural resources by human beings. Land, water, energy sources, air, and space have all been adversely affected through human intervention" (Rajagopalan, 2011, 7). With regard to sub-Saharan Africa, there are various environmental problems that have arisen from excessive and irresponsible use of the resources of nature. Environmental problems in the region include deforestation, desertification, oil spillage, pollution, soil erosion, unplanned urbanisation, overpopulation, destruction of endangered species of plants and animals, wars and conflicts, poverty, mismanagement of domestic and industrial waste, and climate change.

One of the often-unacknowledged sources of the environmental predicament in sub-Sahara Africa is a colonialist ideology. Colonialism was not simply a system that underdeveloped Africa during the colonial era. It is also a system of thought. In the colonial mindset, the only thing that has value is what is useful to man. Land and its resources have no value in themselves; they are there to meet human needs. The environment only counts if it can have value to human life. Colonialists cared nothing about nature's biodiversity. It was driven by the paradigm of carting away mineral resources and other gifts of nature from colonial territory to the imperial metropolis. This mentality that land must be developed, uninhabited land has no value still drives modern development in sub-Saharan Africa. The colonial, the neo-colonial and its destructive impact on the environment are well attested in many 
works (Crosby, 2006; Grove, 2006; Saro-Wiwa, 2006; Plumwood, 2005; Maathai, 2009).

Many governments in sub-Saharan Africa are driven by the mentality of development. Every land must be developed. For them, more roads, more houses and more facilities are always better for development. The built environment continues to destroy more wildernesses in sub-Sahara Africa. While it is true that development should not be discounted, it must be done with great ethical prudence. Wilderness also needs to be preserved. Biodiversity needs to be preserved. Environmental aesthetics should be taken into consideration. The piece Environmental aspect of Economic Development in sub-Saharan Africa is helpful here. In that piece, the author argues that there is a need to replace a traditional concept of economic growth based on economic output alone with one that emphasises development through conservation of African valuable natural resources (Baytas 1991, Abstract).

Another cause of the environmental predicament in sub-Saharan Africa is conflicts and wars. The region has witnessed a number of wars. These include the Liberia Civil War, the Nigerian Civil war, the war in Sierra Leone, conflicts in places like Mali and Mauritania, the war in the Democratic Republic of Congo, the Rwanda Genocide, the conflict in Ethiopia and Somalia among others. In the past, there have also been violent struggles in Namibia, Kenya, etc. Wars often have great negative impacts on people and the natural environment. During wars and conflicts, people are displaced, human insecurity is precipitated, plants and animals are destroyed and the land suffers from pollution caused by war armaments. During the war, social infrastructures are destroyed to deprive the enemy of a source of sustenance. Pipelines are burnt to deprive the enemy of the income from oil. The impact of war on the environment often lingers on for years.

The countries of sub-Sahara Africa are essentially exporters of raw materials. Raw materials from the region include crude oil, diamond, gold, bauxite, iron ore, coal and many others. In the drive to get money to develop, countries in sub-Sahara Africa continue to mine for mineral resources without thinking of the impact on nature. Greed for blood diamond, theft of crude oil, and the violent struggle over natural resources has also contributed to the environmental crisis. The region is inundated with sit-tight dictators who rig elections and want to remain in power for life. The struggle for power at the centre is driven by the desire to control the national finances which many come from the export of natural resources.

The rising population in the region also precipitates environmental distress; the more people there are, the more there is a struggle for scarce mineral resources. The entire region of Sub-Sahara Africa has witnessed rural-urban migration. Urbanisation has often precipitated many problems in urban cities. These include urban slums, pressure on the power supply, unemployment. Urbanisation is also related to industrialisation. There is a drive to build more industries in order to modernise African economies. Industrialisation entails a more built environment and this implies more destruction of the forest.

The lack of adequate environmental impact assessment also hampers environmental protection. Many countries in sub-Sahara Africa have neglected the environmental impact assessment. Even when there are environmental impact assessment regulations, they are hardly implemented. Kakonge has indicated that when it comes to the use of environmental impact assessment, sub-Saharan countries are at a crossroad and that there is a need for sub-Sahara countries to own the process of EIA, committed to funding the process have adequate public sensitisation to end corruption and poor governance for EIA to be effective in the region (Kakonge, 2006, p. 33-35).

\section{Eco-Stewardship, a Critical Appraisal}

What is needed to curb and cure the environmental problems in the region is the practical ethics of ecostewardship. Eco-stewardship, like every human concept has its limitations and advantages. Despite its limitations, it has positive dimensions that should be taken seriously. Before those positive aspects are examined, it is important to note its limitations. It is problematic for it implies that humans are above and superior to nature and that they are to control and rule over nature through science and technology (Bakken, 2009, p. 282). Ecocentrists see the idea of 
stewardship as promoting an absentee God, desacralised nature, and "inflates their (human) importance in creation, and exaggerate their competence to manage or improve the biosphere" (Bakken, 2005, p. 1598). Some perceive stewardship from a religious viewpoint as "inimical to human interests, a threat to economic freedom and individual property rights, and overly pessimistic about technological and market-based solutions to environmental concerns" (Bakken, 2005 , p. 1598). While for others, it can become a mere euphemism for exploitative domination of nature. There are also Christian conservatives who see it as irrelevant to the church's mission, or see it as earth worship and argue that people should focus on the second coming of Christ (Bakken, 2009). The idea of eco-stewardship suffers from the fact that it can become management and control of nature and interventionist as if nature cannot flourish without humans (Bakken, 2009; Jenkins, 2008). Both Matthew Fox and Clare Palmer see stewardship as promoting an absentee God who is separate from nature (Attfield, 2006). Because of its managerial import, there is a need to move beyond stewardship to discover how humans can be with nature, not how they can relate to nature (Vena 2009, 177).

Most of these criticisms come from a narrow understanding or misunderstanding of the concept. That humans are stewards of creation does not imply they can use nature as they desire without ethical restraints. Just as other animals in the food chain or web of nature make use of nature, humans survive by taking from nature. What is required is prudential and non-luxurious use of nature keeping in mind the wellbeing of non-human lives. God is not absent from nature; rather, God is present through human presence as humans are co-creators with God. While it is true that nature existed without humans for millions of years, after the emergence of human life, humans are now an intrinsic part of nature. As part of nature, they need to recognise being part of nature and live with nature. Whether from the lens of evolutionary biology or theism, the emergence of human consciousness from nature, has made humans carriers of knowledge of science and technology. The proposition of Holmes Rolston is worth considering when he argues that human consciousnesses give us power and responsibility that is rooted in human conscience (Rolston, 1995, p. 2).

Human stewardship should not be seen in terms of pyramidal control or vertical hierarchy; rather, humans are at the centre of nature with a conscience to live in friendship with it. Humans should not be denied the right to their own survival in nature. Humans cannot exist without impacting nature. To deny humans an impact in nature is to eliminate humans from life. What is called for is a gentle, peaceful, and harmonious presence in nature.

For those who defend the concept of stewardship, the idea implies that humans are unique beings. They carry tremendous powers to transform, degrade or destroy the planet. The concept of stewardship speaks about human responsibility to take care of the planet and not to destroy it for the good of present and future generations. This is necessary for the era of capitalism and anthropocentric culture (Bakken, 2009). The idea of stewardship can serve a "hortatory function, urging believers to environmental concern and engagement, and an apologetic function, countering claims that the biblical idea of human dominion over nature sanctions environmental rapacity" (Bakken, 2005, p. 1598). It stands both against ecocentrism and aggressive anthropocentrism. Stewardship is a response to the environmental crisis in the works of Francis Schaeffer, Paul Santimire and John Passmore (Jenkins, 2008). Individuals and groups that have enhanced the theory of stewardship include Ron Sider, Calvin De Witt, Evangelicals for Social Action, Au Sable Institute, Evangelical Environmental Network, North American Conference on Christianity and Ecology and World Vision (Jenkins, 2008). Others are the American Baptist Policy Statement on Ecology 1989, Walter Brueggemann, the Presbyterian Church of the US in 1996, and the Catholic Bishops of the Columbia River Watershed (Butkus, 2002). Stewardship of creation aims at sustainability, not domination of the earth.

The viewpoint here is in consonance with the idea that the unique human place in nature is one of true responsibility and service to nature and God, creation exists not simply for human purpose but has intrinsic value. Stewardship which implies management of resources is "primarily...the 
protection of the Earth rather than its improvement, and as deepening humans' involvement with nature rather than detaching them from it" (Bakken, 2005). Bakken is right to note that:

The most plausible interpretations of stewardship fall between the extremes of total disengagement and total management. A restrained approach to stewardship would allow the minimum intervention necessary to maintain a sustainable, just, and dignified human civilisation and protect and restore the species and ecosystem that human activities threaten or have harmed. Although human responsibility would be global in the sense that no part of the earth can be immune from being threatened or influenced by human activities, different degrees of intervention would be appropriate for different types of landscape, for example, more intervention in the domesticated landscape and less in wilderness areas. (Bakken, 2009, p. 284)

Eco-stewardship is not a cure-all for the entire environmental crisis. It needs to be buttressed with positive insights from other eco-images such as from deep ecology, eco-liberation theology, ecofeminism, animal liberation, etc. The insights from those paradigms that can be synthesised with eco-stewardship are not the subject of concern now. It suffices to note that from the idea of stewardship humans need to see themselves as responsible and accountable; if not to God for those who are atheist, at least to future generations, the global community, to one's family and local community. Within the African communitarian theory, the people make up a community and have obligations to that community (Bujo, 2009; Ramose, 2009; Murove, 2009). The resources of nature are not simply for private use. Even private property is a social mortgage (Catholic Bishops, 1965; John Paul II, 1987). It is also imperative to note that: "our vision of stewardship can never only be environmental. It also must address social injustice and poverty, the suffering of all creation, and seek to expose the intrinsic link between the oppression of people and the oppression of all creation" (Butkus, 2002, p. 22). Stewardship must involve radical sharing of resources as this will ameliorate poverty and puts less pressure on the environment. Thomas Aquinas is right to note that property beyond a person's necessity is owned as of right to provide for the poor.

It is this idea of eco-stewardship as responsibility, accountability, and prudent use of nature's resources that should inform human practices in sub-Saharan Africa. The resources of the region are being excessively mined, forests are being extensively degraded, and the land and atmosphere are being polluted with regard to the needs of future generations. It is regrettable to note that the theory of stewardship really features in environmental discourse in the region. It is a fact that the idea of future generations is problematic as they do not yet exist. Yet, the fact also remains that if the present environment and resources that present humans inherited from past generations were communicated to them in the worst state, present generations would have suffered more. Eco-stewardship means that the consideration that present humans inherited the environment from the past and they need to be responsible in using it should condition policies and practices in the region. Present humans did not create nature or place the resources of nature in the ground. It is a heritage from God, the ancestors, or previous generations. They should not misuse or abuse nature.

\section{CONCLUSION}

The foregoing has revealed that the sub-Saharan region is plagued by various environmental problems. Many environmental problems are human-made precipitated by urbanisation and industrialisation, aggressive development, wars, population growth, etc. Environmental damage in the region can be curbed or ameliorated with the ethics of eco-stewardship. The problem is that this ethics is often unknown in the region. What drives people often is control of natural resources for more economic development. The drive to control natural resources without a care for what happens to the environment is compounded by corruption, embezzlement of public funds, ethnic warfare, youth restiveness and the like.

To combat the above problems, the environmental awareness or information of this sense of ecoresponsibility should prevail in the region. Environmental information is vital in environmental preservation (United Nations Conference on the Environment, 1992, Principle 10). People in the 
sub-Saharan region will not be proactive in protecting the environment if they are not aware of the environmental challenges and their responsibility. The values of stewardship in seeing oneself as a person with a conscience who should use his/her knowledge to foster nature should be promoted. There is so much ignorance of environmental issues in the region even among government officials. Your beliefs inform your behaviour. Educational curriculum, government policies, and human behaviour in the region should be driven by the stewardship mandate. Conclusively, if the virtue of eco-stewardship is promoted in the region, it will no doubt help to create an environmentally sustainable sub-Saharan region.

\section{REFERENCES}

Attfield, R. (2006). Chapter 6: Environmental Sensitivity and Critique of Stewardship. In Berry, R. J. (Ed), Environmental Stewardship: Critical Perspectives-Past and Present (pp. 7691). Edinburgh: T \& T Clark Ltd.

Bakken, P. W. (2005). Stewardship. In Taylor, B. (Ed), Encyclopaedia of Religion and Nature (pp. 1598-1599). London: Continuum.

Bakken, P. W. (2009). Stewardship. In Callicott, J. B. \& Frodeman, R. (ed), Encyclopaedia of Environmental Ethics and Philosophy (pp. 282284). Detroit: Gale Cengage Learning.

Baytas, A. (1991). Environmental Aspects of Economic Development in Sub-Saharan Africa. Upper Montclair, NJ: Center for Economic Research on Africa, Montclair State University.

Bujo, B. (2009). Ecology and Ethical Responsibility from an African Perceive. In Murove, M. F. (Ed), African ethics: An Anthology of Comparative and Applied Ethics. Scottsville: University of KwaZulu-Natal Press.

Butkus, R. A. (2002). The stewardship of creation. Moral Landscape of Creation, 17-23.

Catholic Bishops. (1965. December 7). Pastoral Constitution on the Church in the Modern World. Accessed on August 10, 2013 from http://www.vatican.va/archive/hist_councils/ii_ vatican_council/documents/vat-

ii_cons_19651207_gaudium-et-spes_en.html.

Chambers Publishers. (1994). The Chambers Dictionary. Edinburgh: Chambers Harrap Publishers Ltd.

Crosby, A. W. (2006). Ecological Imperialism. In Ashcroft, B., Griffiths, G. \& Tiffin, H. (Ed), The Post-Colonial Studies Reader, $2^{\text {nd }}$ edition (p. 494-506). London: Routledge.

Gorman, J. M. (2007). Stewardship. In Espin, O. O. \& Nickoloff, J. K. (Ed), An Introductory Dictionary of Theology and Religious Studies (pp. 1321-1322). Collegeville: Liturgical Press.

Grove, R. (2006). Green Imperialism. In Ashcroft, B., Griffiths, G. \& Tiffin, H. (Ed), The PostColonial Studies Reader, $2^{\text {nd }}$ edition (p. 498500). London: Routledge.

Hook, P. (2009). The Little Book of Environmental Principles. London: New Holland.

Jenkins, W. (2008). Ecology of Grace: Environmental Ethics and Christian Theology. Oxford: Oxford University Press.

John Paul II. (1987). On Social Concern. In Encyclicals of Pope John Paul II (pp. 675-742). Trivandrum, India: Carmel International Publishing House.

Kakonge, J. O. (2006). Environmental planning in Sub-Saharan Africa: Environmental impact assessment at the crossroads. Working Paper Number 9. Yale School of the Environment.

Lexicon Publishers. (1972). The New Webster's Dictionary of the English Language. New York: Lexicon International - Publishers Guild Group.

Maathai, W. (2009). The Challenge for Africa. Great Britain: Arrow Books.

Mabogunje, A. L. (1995). The environmental challenges in sub-Saharan Africa. Environment: Science and Policy for Sustainable Development, 37(4), 4-10.

Murove, M. F. (2009). An African Environmental Ethic Based on the Concept of Ukama and

76 | This work is licensed under a Creative Commons Attribution 4.0 International License. 
Ubuntu. In Murove, M. F. (Ed), African ethics: An Anthology of Comparative and Applied Ethics, (p. 281-297). Scottsville: University of KwaZulu-Natal Press.

Plumwood, V. (2006). Decolonising Relationships with Nature. In Ashcroft, B., Griffiths, G. \& Tiffin, H. (Ed), The Post-Colonial Studies Reader, $2^{\text {nd }}$ edition (p. 503-506). London: Routledge.

Rajagopalan, R. (2011). Environmental Studies: From Crisis to Cure. Oxford: Oxford University Press.

Ramose, M. B. (2009). Ecology through Ubuntu. In Murove, M. F. (Ed), African ethics: An Anthology of Comparative and Applied Ethics, (p. 308-314). Scottsville: University of KwaZulu-Natal Press.

Rolston, H. (1995). Biology, Ethics, and the Origins of Life: An Introduction. In Rolston, H. (Ed), Biology, Ethics, and the Origin of Life, (p. 1-14). Boston: Jones and Bartlett Publishers.

Saro-Wiwa, K. (2006). Trial Statement. In Ashcroft, B., Griffiths, G. \& Tiffin, H. (Ed), The PostColonial Studies Reader, $2^{\text {nd }}$ edition (p. 501502). London: Routledge

United Kingdom Parliament. (1990). The Environmental Protection Act. Accessed on August $\quad 10, \quad 2013$ from http://www.legislation.gov.uk/ukpga/1990/43/c ontents

United Nations Conference on Environment. (1992). Rio Declaration on Environment and Development. Accessed on August 10, 2013 from https://www.cbd.int/doc/ref/riodeclaration.shtml

Vena, C. J. (2009). Beyond stewardship: Toward an agapeic environmental ethic. Doctoral Thesis. Marquette University 